\title{
RESEARCH ON SOME FRESHWATER FISH CATALASE ACTIVITY - AS A POTENTIAL BIOMARKER FOR ENVIRONMENTAL POLLUTION
}

\author{
Romică CREṬU \\ "Dunarea de Jos" University of Galati, Romania \\ e-mail: romica.cretu@ugal.ro
}

\begin{abstract}
In the last decade studies show that water pollution is a very serious problem, especially since the degree of water pollution plays a key role in the growth and fish multiplication. As a biomarker of environmental pollution, antioxidant enzymes such as catalase (CAT; EC 1.11.1.6) play an essential role in preventing the harmful effects of heavy metals in the tissues of fish. These researches were carried out to investigate the effect of various environment conditions and some pollutant agents on oxidative stress in some aquatic organisms. The enzymatic assay of CAT (in fish organs, e.g., liver, kidney, gill, intestine and brain, as well as in mixture of these organs) was carried out according to standard enzyme assay protocol.

The results showed decrease of CAT activity: the enzymatic activity was $35.89 \pm 1.02 \mu \mathrm{mol} \mathrm{H}_{2} \mathrm{O}_{2} / \mathrm{min} / \mathrm{mg}$ protein to $\mathrm{pH} 7$ and $6.59 \pm 0.47 \mu \mathrm{mol}$ $\mathrm{H}_{2} \mathrm{O}_{2} / \mathrm{min} / \mathrm{mg}$ protein to $\mathrm{pH} 12$. More, the enzymatic activity was $38.1 \pm 0.3 \mu \mathrm{mol}$ $\mathrm{H}_{2} \mathrm{O}_{2} / \mathrm{min} / \mathrm{mg}$ protein to $\mathrm{pH}$ 3. Also, the catalase activity increased with 23 enzymatic units to a less dissolved oxygen concentration $(6.2877 \mathrm{mg} / \mathrm{L})$.

Furthermore, this study indicated that heavy metals, such as $\mathrm{Cr}, \mathrm{Cu}$ and $\mathrm{Zn}$ can inhibit biochemical reactions in various organs of fish. During exposure duration of the fish to a mixture of metal ions the catalase activity decreases from $35.89 \pm 1.02 \mu \mathrm{mol} \mathrm{H}_{2} \mathrm{O}_{2} / \mathrm{min} / \mathrm{mg}$ protein to $23.51 \pm 2.85 \mu \mathrm{mol} \mathrm{H}_{2} \mathrm{O}_{2} / \mathrm{min} / \mathrm{mg}$ protein. On the other hand, as a result of the response of the enzyme system, the catalase activity increases to $36.25 \pm 3.22 \mu \mathrm{mol} \mathrm{H}_{2} \mathrm{O}_{2} / \mathrm{min} / \mathrm{mg}$ protein.
\end{abstract}

KEYWORDS: metallurgy, heavy metals mixture, freshwater fish organs, catalase activity, dissolved oxygen

\section{Introduction}

In the last years, the aquatic organisms are exposed to significant amounts of pollutants from industrial technological processes in various fields and agriculture, another factor being the anthropogenic activities [1-6]. Many of the industrial activities and many of the industrial products serve as sources of heavy metals [7].

In this context, both surface water and groundwater can be contaminated with heavy metals such as $\mathrm{Cu}, \mathrm{Zn}$ and $\mathrm{Cr}$. The accumulation of $\mathrm{Cu}$ in river water, for example, is largely the result of the metallurgical industry's impact on environmental pollution [8].

Since two decades ago Rashed [9] shows that heavy metals such as cadmium and lead present in the tissues of some fish, e.g. Tilapia, can be used as indicators to identify water pollution. Tilapia fish is currently very studied, on the one hand the high growth and on the other hand, adaptability to a wide range of environmental conditions. It also shows a great capacity for growth and breeding [10].

Heavy metals even though play an important role in metabolic processes they may inhibit biochemical reactions when is an increase in their concentration [11].

Moreover, specialized studies [12] showed that the most common heavy metals found in the fish body (cadmium, lead, mercury, zinc, copper, nickel, cobalt, molybdenum, chromium, and tin) may be aquatic pollutants, some of them (cadmium, mercury and lead) even at very low concentrations, through the accumulation in tissues. According to the same study, the fish absorb heavy metals through gills and digestive tract and, in a small measure, through the skin. 
In this context, previous studies [13] demonstrate that antioxidant enzymes such as catalase (CAT) play an essential role in preventing the harmful effects of heavy metals in the tissues of fish. CAT (Figure 1) is an enzyme found in a wide range of plants and animals, but also in aerobic and anaerobic microorganisms.

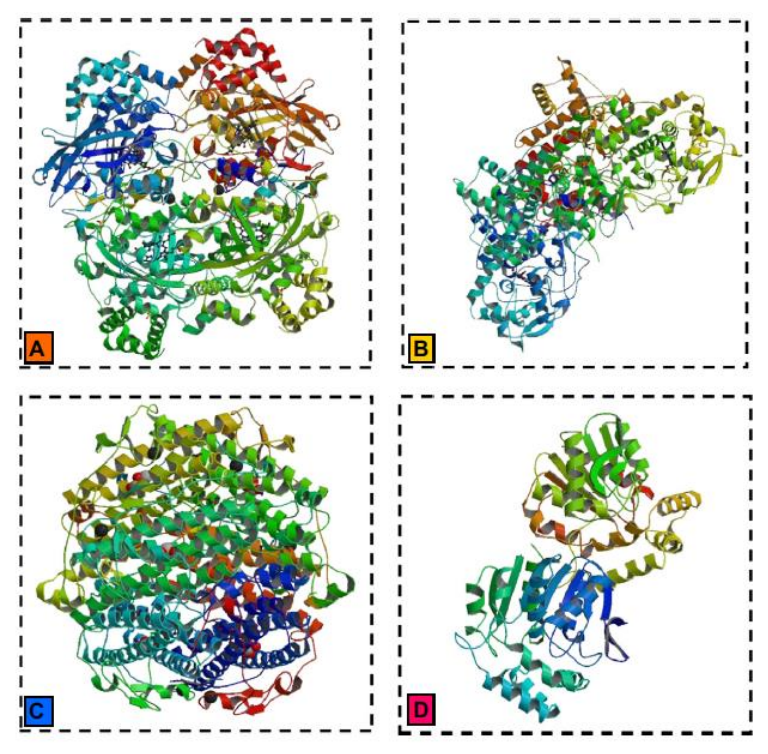

Fig. 1. Different types of catalase: typical catalase (A), atypical catalase (B),

Pseudocatalases $(C)$ and Chloroperoxidase $(D)$. All the figures have been reproduced after [14]

Atli et al. [15] show that this enzyme can be used to determine enzyme activity as identifying indicator for aquatic environment pollution. On the other hand, studies on the internal organs of fish Oreochromis niloticus, such as the liver, kidneys, gills, intestines, and brain, the CAT activity showed response to the action of heavy metals depends on the tissue, metals and their concentration. However, there is no information's about completely activity changes. Furthermore, although in the scientific literature exist studies about the impact of heavy metals on enzyme activity in various organs of fish [16-19] the best of our knowledge there is no article about cumulative and induced enzymatic activity changes for all fish organs.

So, this study shows the results of various environment conditions effect and some pollutant agents on oxidative stress in Oreochromis niloticus fish. Another specific objective of this study is to compare the heavy metals cumulative impact on CAT activity changes in the case of some organs and organs mixture of the Oreochromis niloticus fish.

\section{Materials and methods}

Experimental protocol was realized according to Atli et al. [15] with some modifications. The Oreochromis niloticus fish were obtained from the Department of Food Science, Food Engineering, Biotechnology and Aquaculture of "Dunarea de Jos" University of Galati. These were transferred in safety conditions to the laboratory in a glass aquarium with four compartments containing water for contaminated test solution or controls $(25 \times 25 \times 40 \mathrm{~cm}$ each), where they were acclimatized to $20^{\circ} \mathrm{C} \pm 1{ }^{\circ} \mathrm{C}$.

The aquarium was aerated with air pump so that the dissolved oxygen concentration was $7.033 \pm 0.16$ $\mathrm{mg} \mathrm{O}_{2} / \mathrm{L}$. The dissolved oxygen was daily measured with Hannah HI 98186 oximeter and $\mathrm{pH}$ was determined by electrical method involving the use of a pH-meter (HI 255 Combined Meter $\mathrm{pH} / \mathrm{mV}$ and EC/TDS/NaCl LV2, HANNA equipped with $\mathrm{pH}$ electrode (HI1131B), EC probe (HI 76310) and temperature probe (HI 7662).

The dechlorinated water used in this study for control had a $\mathrm{pH}$ value of $7.47 \pm 0.16$ and conductivity of $602.4 \pm 5.6 \mu \mathrm{S} / \mathrm{cm}$. During experiments the laboratory was illuminated using as a light source a fluorescent lamp (daylight 65/80 W).

Fish were exposed to a mixture of different concentrations of heavy metals for some individual organs such as the liver, kidney, gills, intestines and brain $(\mathrm{Cu}, 0.2$ to $1 \mathrm{mg} / \mathrm{L}, \mathrm{Zn}$ from 0.2 to $1 \mathrm{mg} / \mathrm{L}$, and $\mathrm{Cr}$ from 0.8 to $1.5 \mathrm{mg} / \mathrm{L})$ for 96 hours. For this purpose, $\mathrm{CuCl}_{2} \cdot 2 \mathrm{H}_{2} \mathrm{O}, \mathrm{K}_{2} \mathrm{Cr}_{2} \mathrm{O}_{7}$ and $\mathrm{ZnCl}_{2}$ salts (Sigma or Merck AG, Germany) were used as metal sources.

All fish were euthanized after they were placed in the freezer [20], anesthetized with 2phenoxyethanol and by transaction of the spinal cord according to Atli and Canli [18] at the end of the exposure period. To extract the catalase, an amount of $0.5 \mathrm{~g}$ of fish tissue is homogenized with quartz sand and $5 \mathrm{~mL}$ of a $100 \mathrm{mM}$ solution of disodium phosphate. After 30 minutes conventional extraction and 10 minutes ultrasound extraction (water bath, 35 $\mathrm{kHz}$ ) the homogenate was centrifuged at 10,000 $\mathrm{g}$ (Hettich Universal) for $15 \mathrm{~min}\left(+4{ }^{\circ} \mathrm{C}\right)$. Separate supernatant was served as a source of catalase. The method for enzyme activity evaluation is based on the fact that catalase is allowed to act on the hydrogen peroxide for a fixed period of time. Then the catalase is inactivated by the addition of a mixture of high purity potassium dichromate - glacial acetic acid.

The amount of hydrogen peroxide decomposing remained after stopping the action of catalase, reduces in acidic medium the potassium dichromate to chromic acetate, which can be determined by spectrophotometry. The CAT activity was measured at $570 \mathrm{~nm}$. Because $\mathrm{K}_{2} \mathrm{Cr}_{2} \mathrm{O}_{7}$ does not absorb at this 
wavelength, his presence in the reaction medium does not interfere with the chromic acetate spectrophotometric determination.

The total protein concentration from supernatants of fish tissue was determined according to the method of Lowry et al. [21] with bovine serum albumin (BSA) as standard.

There was no significant difference in weight $(19.157 \pm 3.77 \mathrm{~g})$ between the fish under study, both for control samples and in that of fish exposed to experimental conditions.

Statistical Analysis of data was carried out using SPSS for Windows (standard version 10) statistical package software. The experiment was performed in triplicate.

\section{Results and discussion}

Although it is difficult to collect samples for several internal organs of fish Oreochromis niloticus, the obtained results in this paper suggest that catalase activity measurement can provide important information about environmental pollution. At the same time, measurement of catalase activity can be an alternative to the physico-chemical methods for the detection of pollutants.

The present research shows that under the action of important factors such as $\mathrm{pH}$ and heavy metals, there are changes in CAT activity in all the studied organs. The results of this study are mostly comparable to those that were elaborated by Atli et al. [15] who conducted comparative studies on various internal organs.

\subsection{Studies on the dissolved oxygen concentration}

One of the first objectives was to establish the relationship between the dissolved oxygen content in aquarium water and enzymatic activity during the monitoring of fish activity.

In this case, Figure 2 shows that the low dissolved oxygen exerts severe pressure on catalase activity. Enzymatic activity increases in general as a result of the stress to which the fish are subjected under these experimental conditions.

As can be seen from the analysis of data shown in Figure 2 the catalase activity increased with 23 enzymatic units (EU) approximately (from 47.1899 to $70.0821 \mu \mathrm{mol} \mathrm{H}_{2} \mathrm{O}_{2} / \mathrm{min} / \mathrm{mg}$ protein) to a less dissolved oxygen concentration $(6.287 \mathrm{mg} / \mathrm{L})$ compared to a higher dissolved oxygen (10.898 $\mathrm{mg} / \mathrm{L})$. This increase is justified by the fact that probably the fish has made an extra effort in an environment with less oxygen. At the same time, catalase activity remains almost constant when dissolved oxygen has values: 7.033, 9.417 and 10.898 $(\mathrm{mg} / \mathrm{L})$ respectively. For maintaining normal behavior of aquarium fish studies and optimal conditions for development and breeding research conducted, it preferred to adjust the air flow rate to maintain dissolved oxygen around $7 \mathrm{mg} / \mathrm{L}\left(7.033 \mathrm{mg} \mathrm{O}_{2} / \mathrm{L}\right)$.

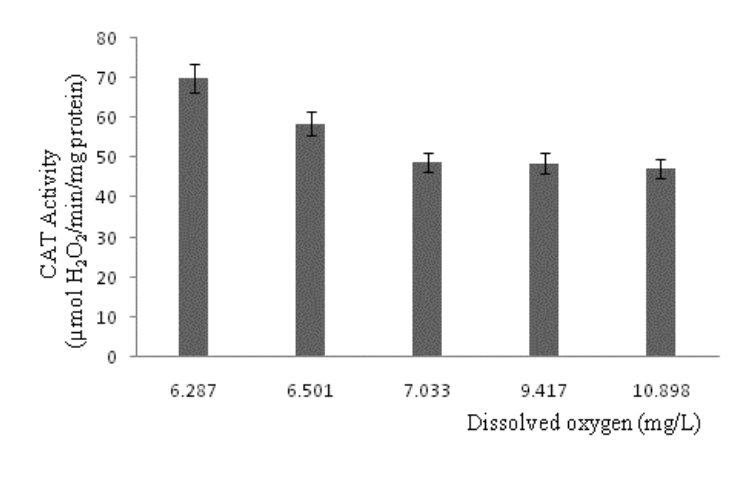

Fig. 2. Catalase activity of Oreochromis niloticus depending on the dissolved oxygen. Vertical bars represent standard deviation of the mean $(n=3)$

\subsection{Analysis of the pH effect}

Initially, pH was ranged from 7 (control) to 12 . According to experimental observations, at extreme $\mathrm{pH}(\mathrm{pH}=12)$, immediately after exposure, the fish activity was relatively low. Also, the gills have become black. Thus, the exposure of the Oreochromis niloticus fish at a highly basic environment for about 1 hour leads to inhibition of catalase activity (Figure 3 ). Experimental results show that after exposure in a strongly basic environment, internal organs of the Oreochromis niloticus tracked in the study are soft, indistinguishable and pungent odor (the results are not shown). These results suggest the high sensitivity of this antioxidant enzyme exposure in highly alkaline conditions. Moreover, the initial pH was varied to $\mathrm{pH} 3$ (Figure 3). No case of mortality was found in this exposure. In the first hours of exposure, no visible differences in the appearance of the fish were observed. Instead, his behavior was completely changed: his activity was completely reduced and his appetite was low. After 24 hours, there was a slight activity, the appetite being just as low. After exposing the fish to acidic medium for $96 \mathrm{~h}$, the appearance of the fish changed, having a much lighter colour than the initial one. Also, as in the case of exposure of fish in conditions of extreme basic $\mathrm{pH}(\mathrm{pH}=12)$, their dissection was difficult, their skin becoming very hard. The internal organs have visibly changed, being soft, difficult to differentiate and with a bad smell (the results are not shown). 


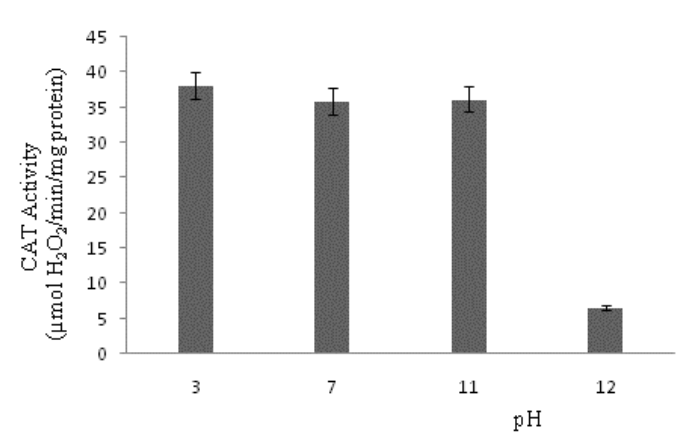

Fig. 3. The effects of $p H$ on CAT activity in some organ's mixture (liver, kidney, gill, intestine and brain) of Oreochromis niloticus. The $\mathrm{pH}$ values correspond to inflection points

Figure 3 show that the enzymatic activity, evaluated in the case of a mixture of internal organs of the studied fish, is influenced by $\mathrm{pH}$ variation.

In this context, there are variations in catalase activity corresponding to the inflection points of the pH values: $38.1 \pm 0.3 \mu \mathrm{mol} \mathrm{H}_{2} \mathrm{O}_{2} / \mathrm{min} / \mathrm{mg}$ protein $(\mathrm{pH}$ = 3), $35.89 \pm 1.02 \mu \mathrm{mol} \mathrm{H}_{2} \mathrm{O}_{2} / \mathrm{min} / \mathrm{mg}$ protein $(\mathrm{pH}=$ 7), $36.14 \pm 0.29 \mu \mathrm{mol} \mathrm{H}_{2} \mathrm{O}_{2} / \mathrm{min} / \mathrm{mg}$ protein $(\mathrm{pH}=$ 11) and $6.59 \pm 0.47 \mu \mathrm{mol} \mathrm{H}_{2} \mathrm{O}_{2} / \mathrm{min} / \mathrm{mg}$ protein $(\mathrm{pH}=$ 12).

According to the results shown in Figure 3, regarding the evolution of enzymatic activity under the impact of sub-lethal $(\mathrm{pH}=11)$ and lethal $(\mathrm{pH}=$ 12) $\mathrm{pH}$, the alarming decrease in catalase activity by approximately $82 \%$ suggests severe enzyme inhibition.

Also, these results indicate a decrease with $6 \%$ in terms of catalase inactivation under extreme conditions, at $\mathrm{pH}=2$. In this case the enzymatic activity was $35.82 \pm 0.53 \mu \mathrm{mol} \mathrm{H}_{2} \mathrm{O}_{2} / \mathrm{min} / \mathrm{mg}$ protein (the results are not show in Figure 3). However, this situation corresponds to the death condition, according to the obtained results. Consequently, Oreochromis niloticus fish have a much better resistance in an acidic environment compared to a basic one. Because the fish exposed in a basic environment $(\mathrm{pH}=11)$ managed to survive, it can be concluded that Oreochromis niloticus fish have a good resistance.

However, it can be considered that the results in terms of catalase activity, on exposure to basic medium, cannot be conclusive, the difference between the enzymatic activities corresponding to the sub-lethal and lethal basic $\mathrm{pH}$ being about $30 \mathrm{EU}$. In contrast, there is a difference of less than $3 \mathrm{EU}$ between the enzymatic activities corresponding to neutral and acidic (not lethal) $\mathrm{pH}$. This suggests that although catalase activity is also slightly inhibited in this unfavourable living environment due to metabolic disturbance, the impact in this case is ten times lower than in the basic environment.

Therefore, in order to prevent the toxic effect associated with the variation of fish habitat, expressed in terms of $\mathrm{pH}$, it can be monitored by determining the enzymatic activity. As a result, more detailed monitoring of this parameter is desirable.

\subsection{Effects of some metal ions on the antioxidant enzyme activities of Oreochromis niloticus intern organs}

Some metals, although toxic at certain concentrations, may act as catalysts in the oxidative reactions of biological macromolecules. Some metals, such as copper and chromium, undergo redox cycles, and others, such as cadmium, deplete antioxidants in cells. Such metals, whose action is pursued in the present study, can cause oxidative stress and therefore lead to dysfunctional abnormalities in various biomolecules such as lipids, proteins and DNA [22].

According to the results of this paper, heavy metals can alter metabolism, activating or inhibiting catalase, and these changes in enzymatic activity can cause metabolic changes and cellular destruction of internal organs. Experimental research has suggested that measuring enzymatic activity may be an effective biomarker of chemical pollution, in line with other recent scientific findings in the literature [23].

The highlighting of the impact produced by some heavy metals on the enzymatic activity followed in this study is presented in Figure 4.

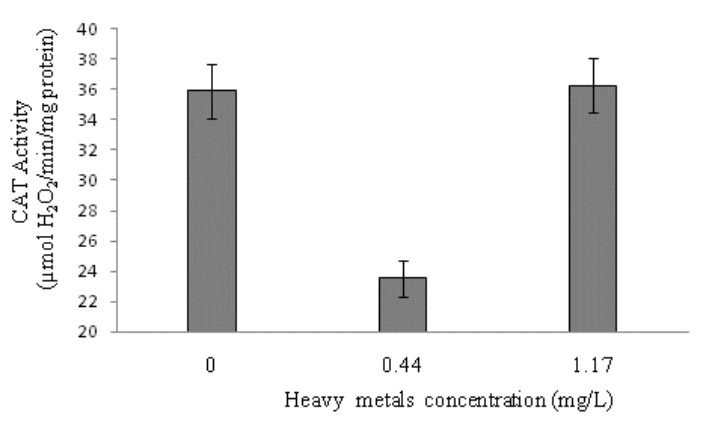

Fig. 4. CAT activities in the mixture of some organs (intestine, liver, kidney, gill and brain) of O. niloticus after $\mathrm{Cu}^{2+}, \mathrm{Zn}^{2+}$ and $\mathrm{Cr}^{6+}$ mixture (1:1:1) exposures

Figure 4 shows the results obtained on the exposure of fish to concentrations of heavy metals similar to those reported in the research of other specialized works in which the enzymatic activity is minimal and maximum, respectively [10], but using a mixture of these metals. According to the data in Figure 4 , there are visible differences in the case of 


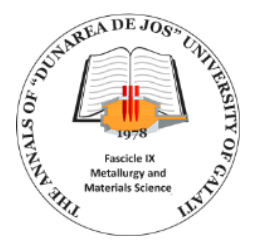

exposure to the minimum concentration studied $(0.44$ $\mathrm{mg} / \mathrm{L}$ ), the catalase activity decreasing by approximately 12 EU from $35.89 \pm 1.02 \mu \mathrm{mol}$ $\mathrm{H}_{2} \mathrm{O}_{2} / \mathrm{min} / \mathrm{mg}$ protein to (control sample value) to $23.51 \pm 2.85 \mu \mathrm{mol} \mathrm{H}_{2} \mathrm{O}_{2} / \mathrm{min} / \mathrm{mg}$ protein. More so, as a result of the response of the enzyme system, when the concentration of the heavy metal mixture increases, there is an intensification of the enzyme activity with $1 \%$ approximately compared to the value of the control sample. Thus, exposure of fish to a mixture of $1.17 \mathrm{mg} / \mathrm{L} \mathrm{Cu}^{2+}, \mathrm{Zn}^{2+}$ and $\mathrm{Cr}^{6+}$ has as a result in a slight increase in catalase activity.

The increase in catalase activity after exposure of fish to the studied metal ion mixture from 0.44 $\mathrm{mg} / \mathrm{L}$ to $1.17 \mathrm{mg} / \mathrm{L}$ may be associated with increased oxidative stress [24] due to the presence of heavy metals in aquarium water.

Therefore, CAT inhibition in the presence of the metal ion mixture can be attributed to the direct effect of metal exposure due to the formation of direct bonds of metal ions to the catalase molecule. In this context, finally there is an increase in hydrogen peroxide radicals. Thus, the experimental results of this study on the total impact of heavy metals, at sublethal concentrations, on some organs of Oreochromis niloticus fish showed that the catalase activity can be used as a biomarker in terms of environmental pollution.

Research has been extended to fish exposed to lethal concentrations (LC) of heavy metals, when the catalase activity is $15.946 \pm 5.46 \mu \mathrm{mol} \mathrm{H}_{2} \mathrm{O}_{2} / \mathrm{min} / \mathrm{mg}$ protein (Figure 5).

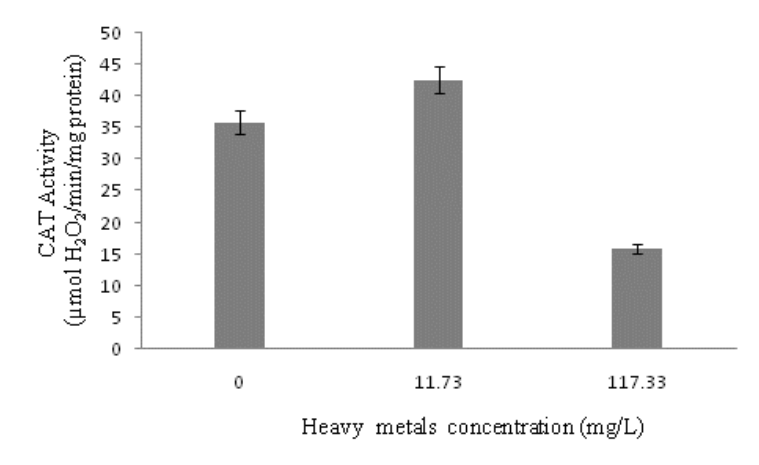

Fig. 5. CAT activities in some organs mixture (liver, kidney, gill, intestine, and brain) of Oreochromis niloticus after higher concentrations of $\mathrm{Cu}^{2+}, \mathrm{Zn}^{2+}$ and $\mathrm{Cr}^{6+}$ mixture exposures (as explained in Figure 4)

The data presented in Figure 5 highlight the increase in catalase activity of approximately 6.74 EU at exposure to a mixture of heavy metals at a concentration ten times higher than the highest concentration in the initial study, which demonstrates catalase activation under these conditions. However, catalase activity decreased dramatically by approximately $20 \mathrm{EU}$ in case of exposure to a concentration (LC) 100 times higher than the maximum shown in Figure 4, when the death of the fish was ascertained. The concomitant presence of heavy metals $\mathrm{Cu}, \mathrm{Zn}$ and $\mathrm{Cr}$ in water eventually leads to a decrease in the activity of antioxidant enzymes, such as catalase, due to its inhibitory effect on it. Therefore, a significant decrease in the enzymatic activity of catalase in Oreochromis niloticus is an indicator of short-, medium- and long-term environmental pollution.

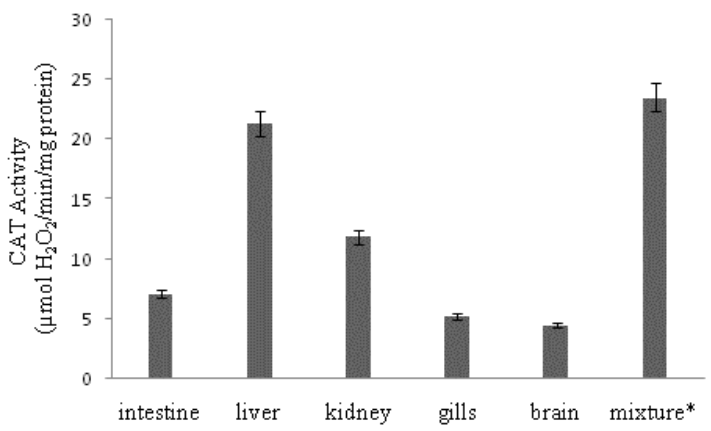

(a)

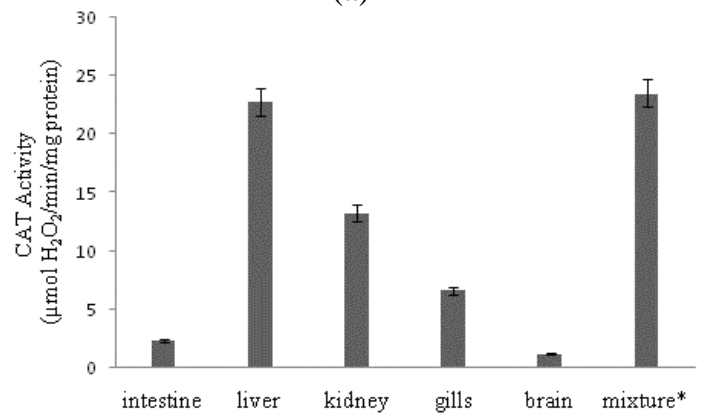

(b)

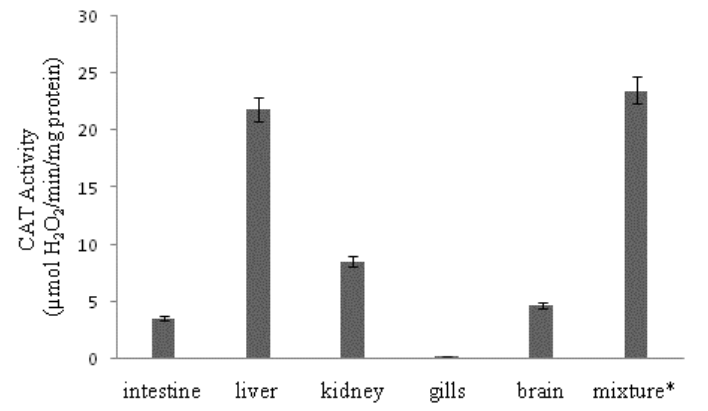

(c)

Fig. 6. Comparative evaluation of the CAT activity in some organs and their mixtures (see Figures 4 and 5 for details) of Oreochromis niloticus after lower concentrations $(0.44 \mathrm{mg} / \mathrm{L})$ of $\mathrm{Cu}^{2+}(\mathrm{a}), \mathrm{Zn}^{2+}(\mathrm{b})$ and $\mathrm{Cr}^{6+}(c)$ exposures *organs mixture to the lower sub-lethal concentrations of the heavy metals 


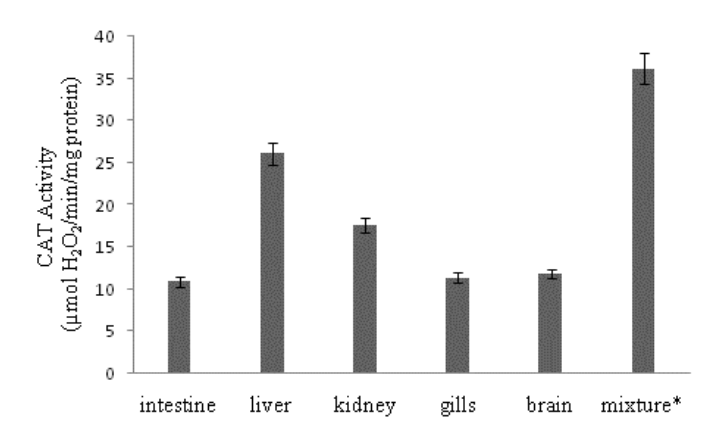

(a)

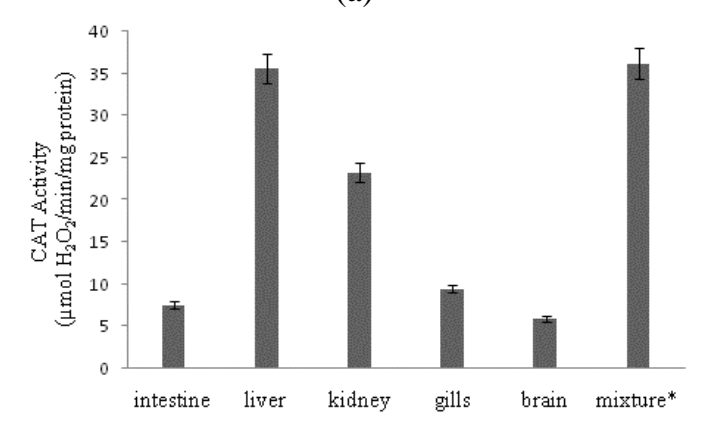

(b)

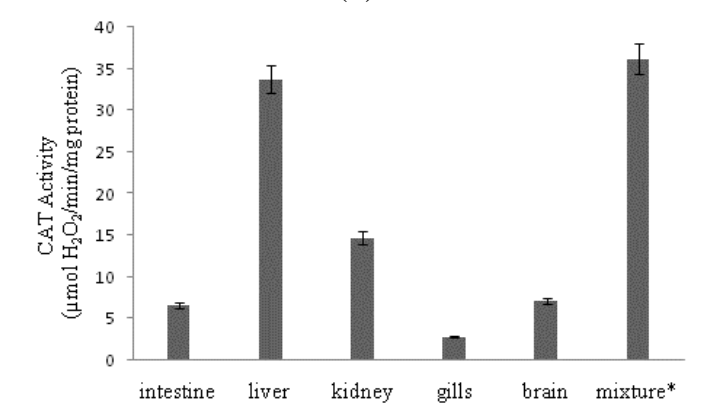

(c)

Fig. 7. Comparative evaluation of the CAT activities in some organs and their mixtures (see

Figures 4 and 5 for details) of Oreochromis niloticus after the highest concentrations (mean of the concentrations: $11.73 \mathrm{mg} / \mathrm{L})$ of $\mathrm{Cu}^{2+}(a)$, $\mathrm{Zn}^{2+}(b)$ and $\mathrm{Cr}^{6+}(c)$ exposures.

${ }^{*}$ organs mixture to the highest sub-lethal concentrations of the heavy metals

Results regarding the effect of some heavy metals $\left(\mathrm{Cu}^{2+}, \mathrm{Zn}^{2+}\right.$ and $\left.\mathrm{Cr}^{6+}\right)$ on some organs of Oreochromis niloticus fish, compared to the cumulative effect of these metals on the mixtures of some organs (intestines, liver, kidney, gill and brain) are reported in Figures 6 and 7. The research was performed using some concentrations, considered inflection points in the variation of the enzymatic response.

As shown in Figure 7 the differences are often remarkable. The enzymatic response to the action of the pollutant depends primarily on its type and concentration, but also on the type of organ affected. It seems that the contribution of the liver is the largest of all the organs studied to the response of the enzymatic system of the Oreochromis niloticus fish organism to the cumulative action of heavy metals.

This variation in the impact of heavy metals on the internal organs of Oreochromis niloticus fish, for example, brain, kidneys, gills and intestines, shown in Figure 7, indicates a more aggressive action and, consequently, a more negative impact on fish when in water are present simultaneously some heavy metals, such as $\mathrm{Cu}, \mathrm{Zn}$ and $\mathrm{Cr}$.

Moreover, the correlation coefficients between the CAT activity values for all types of organs studied (Table 1) showed that there are significant correlations between certain organs depending on the concentration of heavy metals to which they are exposed.

These results suggest that the study of the cumulative action of heavy metals on Oreochromis niloticus fish by using advanced methods of statistical analysis of enzymatic activity is effective and allows the optimal evaluation of their response to the action of heavy metals.

As shown in Table 1 in the cases of catalase activity in kidney (CAT-K) and catalase activity in gill (CAT-G) the relationships were significant between these parameters depending on the concentration of heavy metals. Furthermore, CAT-G values correlated positively with catalase activity in intestine (CAT-I) only when the concentration of heavy metals increases significantly. Also, the data in Table 1 suggests that CAT-I showed there were significant positive correlations with catalase activity in gill (CAT-G) and catalase activity in brain (CATB), but also significant negative correlations with catalase activity in liver (CAT-L). Furthermore, significant negative correlations and moderate positive correlations between CAT-L and CAT-B were determined in the case of both concentrations of heavy metals analysed. 
Table 1. Pearson linear correlation coefficients between the values of CAT in the case of the heavy metals $\left(\mathrm{Cu}^{2+}, \mathrm{Zn}^{2+}\right.$ and $\left.\mathrm{Cr}^{6+}\right)$ mixture ${ }^{a, b}$

\begin{tabular}{|c|c|c|c|c|c|}
\hline & CAT-I & CAT-L & CAT-K & CAT-G & CAT-B \\
\hline \multicolumn{6}{|c|}{${ }^{\mathrm{a}}$ lower concentration $(0.44 \mathrm{mg} / \mathrm{L})$} \\
\hline CAT-I & 1.000 & & & & \\
\hline CAT-L & -0.891 & 1.000 & & & \\
\hline CAT-K & -0.016 & 0.468 & 1.000 & & \\
\hline CAT-G & 0.068 & 0.392 & 0.997 & 1.000 & \\
\hline CAT-B & 0.649 & -0.924 & -0.771 & -0.715 & 1.000 \\
\hline \multicolumn{6}{|c|}{${ }^{\mathrm{b}}$ highest concentrations $(11.73 \mathrm{mg} / \mathrm{L})$} \\
\hline CAT-I & 1.000 & & & & \\
\hline CAT-L & -0.920 & 1.000 & & & \\
\hline CAT-K & 0.023 & 0.371 & 1.000 & & \\
\hline CAT-G & 0.813 & -0.520 & 0.600 & 1.000 & \\
\hline CAT-B & 0.920 & -0.998 & -0.371 & 0.520 & 1.000 \\
\hline
\end{tabular}

Abbreviations: CAT-I, catalase activity in intestine; CAT-L, catalase activity in liver;

CAT-K, catalase activity in kidney; CAT-G, catalase activity in gill; CAT-B, catalase activity in brain. Marked correlations are significant at $\mathrm{p}<0.05$

\section{Conclusions and future perspectives}

These results indicate that catalase activity plays an important role in the body's defense against oxidative stress induced by extreme variations of the air flow, $\mathrm{pH}$ and concentration of heavy metals.

Accumulation of heavy metals in fish from contaminated water is an important aspect in terms of environmental awareness, this action leading to damage to all products from the food chain of fish, including fish. This study emphasized that the catalase is very sensitive to the action of some metals e.g., $\mathrm{Cu}, \mathrm{Zn}, \mathrm{Cr}$ on the all-intern organs of the fish when these heavy metals concentration exceeds some limits. Also, low and especially high $\mathrm{pH}$ values exposure strong affects CAT activity. The duration of the exposure time also plays an important role.

Given the fact that aquatic organisms are very sensitive to metal exposure, I had the opportunity to highlight as much information related to oxidative stress induction and other adverse effects of pollution. According to obtained experimental results, when heavy metals are present concurrently, the effect on the internal organs of the fish indicates a negative impact and therefore more aggressive action.

Although this study made reference to cumulative catalase activity changes induced in fish organs (liver, kidney, gills, intestines and brain) of Oreochromis niloticus species by exposing them to the variation of two of the most important water physical-chemical parameters, future research consists in a study on the impact of heavy metals on the specific enzymatic activity of various organs on other categories of fish.
The results obtained in this paper can contribute to the establishment of a database for monitoring the impact of pollutants on the environment through biochemical analyses.

\section{Acknowledgements}

I would like to thank the Department of Food Science, Food Engineering, Biotechnology and Aquaculture of "Dunarea de Jos" University of Galati for providing necessary Oreochromis niloticus fish.

\section{References}

[1]. Demirak A., Yilmaz F., Tuna L. A., Ozdemir N., Heavy metals in water, sediment and tissues of Leuciscus cephalus from a stream in southwestern Turkey, Chemosphere, 63, p. 1451-8, 2006. [2]. Ivanciuc T., Ivanciuc O., Klein D. J., Modelling the bioconcentration factors and bioaccumulation factors of polychlorinated byphenils with posetic quantitative superstructure/activity relationships (QSSAR), Mol Divers, 10, p. 13345, 2006.

[3]. Agah H., Leemakers M., Elskens M., Fatemi S. M. R., Baeyens W., Accumulation of trace metals in the muscles and liver tissues of five fish species from the Persian Gulf, Environ Monit Assess, 157, p. 499-514, 2009.

[4]. Uysal K., Köse E., Bülbül M., Dönmez M., Erdogan Y., Koyun M., The comparison of heavy metal accumulation ratios of some fish species in Enne Dame Lake (Kütahya/Turkey), Environ Monit Assess, 157, p. 355-362, 2009.

[5]. Bereswill R., Streloke M., Schulz R., Current-use pesticides in stream water and suspended particles following runoff: exposure, effects, and mitigation requirements, Environ Toxicol Chem, 32 (6), p. 1254-1263, 2013.

[6]. Jinling L., Xiangrong X., Shen Y., Hefa C., Yiguo H., Xinbin F., Mercury pollutionin fish from South China Sea: Levels, species-specific accumulation, and possible sources, Environmental Research, 131, p. 160-164, 2014.

[7]. Demaku S., Jusufi K., Kastrati G., Contamination of Environment with the Heavy Metals Emitted from a Cement 


\section{THE ANNALS OF “DUNAREA DE JOS” UNIVERSITY OF GALATI \\ FASCICLE IX. METALLURGY AND MATERIALS SCIENCE \\ $\mathrm{N}^{\circ} .4$ - 2021, ISSN 2668-4748; e-ISSN 2668-4756 \\ Article DOI: https://doi.org/10.35219/mms.2021.4.04}

Factory, Kosovo, Journal of Ecological Engineering, 21 (8), p. 7583, 2020.

[8]. Kumari S., Mishra A., Heavy Metal Contamination, In: Marcelo L. Larramendy, Sonia Soloneski (Eds.), Soil Contamination - Threats and Sustainable Solutions, https://doi.org/10.5772/intechopen.93412, 2021.

[9]. Rashed M. N., Cadmium and Lead levels in fish (Tilapia nilotica) tissues as biological indicator for lake water pollution, Environmental Monitoring and Assessment, 68, p. 75-89, 2001.

[10]. Zvavahera C., Hamandishe V., Saidi P., ImbayarwoChikosi V., Nhiwatiwa T., Growth Performance, Survival and Breeding of Oreochromis Niloticus and Oreochromis Macrochir Reared Under Greenhouse Conditions, Aquatic Research, 1 (1), p. 1-11., 2018.

[11]. Kojadinovic J., Potier M., Le Corre M., Cosson R. P., Bustamante P., Bioaccumulation of trace elements in pelagic fish from the Western Indian Ocean, Environ Pollut., 146, p. 548-66, 2007.

[12]. Sfakianakis D. G., Koumoundouros G., Divanach P., Kentouri M., Osteological development of the vertebral column and of the fins in Pagellus erythrinus, 1758, 2004.

[13]. Gül S., Belge-Kurutaş E., Yildiz E., Sahan A., Doran F. Pollution correlated modifications of liver antioxidant systems and histopathology of fish (Cyprinidae) living in Seyhan Dam Lake, Turkey, Environment international, 30 (5), p. 605-609, 2004.

[14]. Balwinder S., Baljinder S. K., Munish P., Recent insights into microbial catalases: Isolation, production and purification, Biotechnology Advances, 32, p. 1429-1447, 2014.

[15]. Atli G., Alptekin O., Tukel S., Canli M., Response of catalase activity to $\mathrm{Ag}^{+}, \mathrm{Cd}^{2+}, \mathrm{Cr}^{6+}, \mathrm{Cu}^{2+}$ and $\mathrm{Zn}^{2+}$ in five tissues of fresh water fish Oreochromis niloticus, Comp. Biochem. Physiol, 143 , p. 218-224, 2006.
[16]. Canli M., Atli G., The relationships between heavy metal $(\mathrm{Cd}, \mathrm{Cr}, \mathrm{Cu}, \mathrm{Fe}, \mathrm{Pb}, \mathrm{Zn})$ levels and the size of six Mediterranean fish species, Environ Pollut, 121, p. 129-136, 2003.

[17]. Birungi Z., Masola B., Zaranyika M. F., Naigaga I., Marshall B., Active biomonitoring of trace heavy metals using fish (Oreochromis niloticus) as bioindicator species. The case of Nakivubo wetland along Lake Victoria, Physics and Chemistry of the Earth, 32, p. 1350-1358, 2007.

[18]. Atli G., Canli M., Response of antioxidant system of freshwater fish Oreochromis niloticus to acute and chronic metal $(\mathrm{Cd}, \mathrm{Cu}, \mathrm{Cr}, \mathrm{Zn}, \mathrm{Fe}$ ) exposures, Ecotoxicology and environmental safety, 73 (8), p. 1884-1889, 2010.

[19]. Abdel-Baki A. S., Dkhil M. A., Al-Quraishy S., Bioaccumulation of some heavy metals in tilapia fish relevant to their concentration in water and sediment of Wadi Hanifah, Saudi Arabia. Afr. J. Biotechnol., 10, p. 2541-2547, 2011.

[20]. Aladesanmi O. T., Agboola F. K., Okonji R. E., Enzymes as Biomarkers of Environmental Stress in African Catfish (Clarias gariepinus) in Osun State, Nigeria. Journal of health and pollution, 7 (14), p. 71-83, 2017.

[21]. Lowry O. H., Rosebrough N. J., Farr A. L., Randall R. J., Protein measurement with the Folin phenol reagent, The Journal of biological chemistry, 193 (1), p. 265-275, 1951.

[22]. Pinto E., Sigaud-Kutner T. C. S., Leitao M. A. S., Okamoto O. K., Morse D., Colepicolo P., Heavy metal-induced oxidative stress in algae, J. Phycol., 39, p. 1008-1018, 2003.

[23]. Olena Yu. V., Olga I. K., Kenneth B. S., Volodymyr I. L., Catalase activity as a potential vital biomarker of fish intoxication by the herbicide aminotriazole, Pesticide Biochemistry and Physiology, 101, p. 1-5, 2011.

[24]. Ercal N., Gurer-Orhan H., Aykin-Burns N., Toxic metals and oxidative stress part I: mechanisms involved in induced oxidative damage, Curr. Top. Med. Chem., 1, p. 529-539, 2001. 